\title{
PRINSIP KERJA SAMA DALAM PERCAKAPAN BERBAHASA INGGRIS DI RADIO
}

\author{
Suko Winarsih \\ Universitas Kanjuruhan Malang \\ Email: farida.umi34@yahoo.com
}

\begin{abstract}
Abstrak: Studi ini bertujuan mendeskripsikan prinsip kerja sama dalam percakapan berbahasa Inggris melalui telepon di radio Mas FM. Penelitian ini menginvestigasi dua masalah, yaitu (1) rentang penggunaan prinsip kerja sama, dan (2) tujuan si penutur dalam ranah tindak ilokusi. Prinsip kerja sama mempunyai empat maksim, kuantitas, kualitas, hubungan, dan cara. Tindak ilokusi mempunyai empat fungsi: bersaing, beramah tamah, berkolaborasi, dan bertentangan. Desain penelitian adalah kualitatif. Subjek penelitian adalah para partisipan tutur: presenter, tamu di studio, dan pendengar. Hasil analisis data menunjukkan bahwa secara umum keempat maksim dalam prinsip kerja sama diaplikasikan oleh partisipan tutur. Tindak tutur yang diaplikasikan oleh para parisipan tutur adalah fungsi bersaing, beramah tamah, dan berkolaborasi. Sedangkan fungsi bertentangan tidak diaplikasikan oleh para partisipan tutur.
\end{abstract}

Kata kunci: maksim, partisipan tutur, dan tindak ilokusi,

Abstract: The study is to describe the cooperative princples found in English conversation via telephone in Mas FM Radio. The study investigates two problems (1) the range of the use of cooperative principles, (2) the goal of the speakers in carrying out the illocutionary act. Cooperative principle has four maxims: quantity, quality, relation, and manner. Illocutionary act has four functions: to compete, to be friendly, to collaborate, and to confront. The design of the research is qualitative. The subjects of the research are the participants: presenter, guests in studio, and audience. The result of the analysis shows that, generally the four maxims in cooperative principles have been applied by the participants in their conversations. The speech acts which are carried out by the participants are competing function, being friendly, and collaborating. On the other hand, the confronting function was not applied by the participants.

Keywords: maxims, participants, and illocutionary act

\section{Pendahuluan}

Edmondson (1981:69) menyatakan bahwa komunikasi verbal merujuk pada interaksi wicara yang melibatkan sedikitnya dua partisipan, yaitu penutur dan mitra tutur yang dapat saling berganti peran. Percakapan terjadi pada situasi yang tidak terformulasikan secara sengaja, dengan tanpa kaidah khusus. Hal ini berarti bahwa suatu percakapan mempersyaratkan topik pembicaraan khusus dalam situasi alamiah. Pendek kata, studi percakapan menghadirkan dua aspek, yaitu topik dan tujuan percakapan.

Percakapan merupakan suatu wacana lisan yang bertipe multi sumber 
secara khusus. Edmondson (1981:5) menyatakan bahwa percakapan mempunyai dua macam berdasarkan cara penutur dan mitra tutur melakukan percakapan tersebut. Kedua macam percakapan itu adalah percakapan tatap muka (face-to-face verbal conversation) dan and percakapan dengan tidak bertatap muka (non face-to-face verbal conversation). Yang pertama merujuk pada percakapan dengan para partisipan, penutur dan mitra tutur bertemu. Pada situasi tertentu, informasi atau pesan yang disampaikan oleh penutur didukung oleh gestur, kinesik, mimik, intonasi, dan sebagainya. Selain itu, penutur dapat dengan cepat bereaksi terhadap reaksi nonverbal pada diri mitra tutur. Yang kedua merujuk pada percakapan verbal dengan partisipan, yaitu penutur dan mitra tutur tidak bersemuka, tetapi melalui alat tertentu, misalnya telepon.

Penelitian ini menginvestigasi percakapan tidak bersemuka (non face-toface verbal conversation), khususnya percakapan melalui telepon. Percakapan telepon menarik diinvestigasi karena percakapan tersebut terjadi tanpa kehadiran para partisipan tuturnya di suatu tempat tertentu, sehingga peran pemindahgiliran sangatlah penting. Setiap partisipan tutur haruslah sabar menunggu waktu yang tepat untuk berbicara. Jika tidak akan terjadi kekacauan percakapan, yaitu para partisipan akan berbicara pada waktu bersamaan. Selain itu, para partisipan haruslah dapat bekerja sama dalam memainkan peran sebagai penutur dan mitra tutur karena percakapan tersebut berlangsung tanpa bantuan gestur, kinesik, dan mimik. Kesimpulannya, sangatlah penting bagi para partisipan tutur menerapkan prinsip kerja sama dalam melakukan percakapan tidak bersemuk, khususnya percakapan melalui telepon.

Penelitian ini merupakan studi pragmatik. Pragmatik berhubungan dengan aspek struktur dan prinsip-prinsip bahasa.
Pragmatik mempelajari hubungan antara bahasa dan konteks yang terkodifikasikan di dalam struktur bahasa (Levinson, 1983:9) Ahli pragmatik dapat menganalisis wacana, khususnya dalam hal implikatur atau prinsip-prinsip percakapan sebagaimana diilustrasikan oleh Grice (dalam Leech, 1983: 21). Lebih jauh, Leech (1983:5) menyatakan bahwa pragmatik berhubungan dengan rasa dalam bertutur, yang dikenal dengan daya pragmatik. Daya pragmatik ini secara relatif bersifat langsung dan tidak langsung. Dengan kata lain, implikatur percakapan mengklarifikasikan perbedaan antara makna literal dan penggunaan ujaran secara kontekstual.

Maksim-maksim pada prinsip kerja sama tersebut berupa konsep normatif, seperti kaidah, norma, prinsip dan lain-lain. Prinsip kerja sama mempunyai empat maksim: (1) kuantitas (quantity),(2) kualitas (quality), (3) hubungan (relation), dan cara (manner). Tujuan penutur dalam percakapan mengandung tindak ilkokusi (illocutionary acts / IA). Leech (1983:104) mengkategorikan tindak ilokusi berdasarkan fungsinya mencakup empat macam: (1) bersaing (competitive), beramah tamah (convivial), bekolaborasi (collaborative), dan bertentangan (conflictive). Edmondson (1981:30) mendeskripsikan tindak ilokusi sebagai ujaran yang mengungkapkan perasaan, sikap, keyakinan, dan perhatian penutur yang berhubungan dengan peristiwaa-peristiwa tertentu. Dengan demikian, tindak ilokusi merupakan ujaran atau performansi yang dikemukakan oleh penutur untuk mengomunikasikan pesan tertentu kepada mitra tutur sebagaimana hal yang diharapkan oleh penutur kepada mitra tutur, yang mempunyai dampak tertentu bagi mitra tutur tersebut.

Di dalam peristiwa komunikasi seorang penutur mengomunikasikan keinginan, perasaan dan pemikirannya kepada mitra tutur dan berharap mereka 
mengerti hal yang disampaikannya. Dengan demikian, seorang penutur selalu mencoba membuat hal yang disampaikannya dapat dipahami orang lain sesuai dengan konteksnya. Hal ini mengindikasikan bahwa si penutur tidak membuang dan menyia-nyiakan waktu selama percakapan tersebut berlangsung. Dalam hal ini terdapat beberapa ptinsip atau maksim percakapan yang memandu terjalinnya kerja sama di dalam percakapan tersebut. Mitra tutur dapat menangkap makna ujaran hanya apabila si penutur dan mitra tutur bekerja sama. Dalam hal ini, Grice (dalam Renkema, 1993:10) mengajukan teori prinsip-prinsip kerja sama (Cooperative Principles). Maksim-maksim pada prinsip kerja sama tersebut dapat digunakan untuk mendeskripsikan bagaimana para partisipan tutur di dalam suatu percakapan menurunkan implikatur. Analisis Wacana dan Pragmatik mempertimbangkan prinsip kerja sama yang merujuk pada pendeskripsian cara mitra tutur memperoleh pesan dari ujaran meskipun pesan tersebut tidak dinyatakan secara eksplisit. Investigasi prinsip kerja sama dalam percakapan berbahasa Inggris di radio dilakukan karena enam alasan sebagai berikut ini.

Pertama, percakapan verbal adalah suatu peristiwa penyampaian informasi atau pesan secara lisan yang sering ditemukan di dalam kehidupan nyata sehari-hari yang membahas berbagai macam topik. Kedua, suatu hal yang sangat menarik menginvestigasi cara para partisipan tutur menerapakan prinsip kerja sama, sebagaimana diajukan oleh Grice dan Leech dalam melakukan percakapan melalui telepon secara langsung siar (on air) di radio dalam suatu program tertentu. Ketiga, keingintahuan peneliti tentang kedinamisan berbagai topik sederhana tetapi menarik yang dikemukakan di dalam acara radio tersebut. Keempat, suatu hal yang sangat menarik menginvestigasi: (1) bagaimana para partisipan percakapan di radio, pendengar dan penyiar mengaplikasikan prinsip kerja sama. (2) apakah para partisipan memenuhi atau melanggar prinsisp kerja sama, (3) dalam kondisi yang bagaimana para partisipan tersebut memenuhi atau melanggar prinsip kerja sama, dan (4) alasan apa yang membuat para partisipan melakukan pemenuhan atau pelanggaran terhadap prinsipp kerja sama tersebut. Kelima, percakapan berbahasa Inggris di sebuah acara di radio tersebut diteliti dalam hal pengaplikasian prinsip kerja sama dan sekaligus pengaplikasian penggunaan tindak ilokusinya. Keenam, Radio Mas FM dipilih sebagai objek penelitian karena radio itu merupakan satu-satunya stasiun radio di kota Malang yang mempunyai program acara percakapan dalam bahasa Inggris melalui telepon secara langsung, yang ditujukan kepada para pendengar yang ingin berlatih menggunakan bahasa Inggris melalui percakapan secara langsung.

Percakapan verbal melalui telepon pada sebuah program acara di radio dapat dianalisis menggunakan pendekatan pragmatik. Pragmatik mempelajari penggunaan bahasa di dalam kehidupan nyata. Para ahli pragmatik memberikan definisi pragmatik dalam berbagai istilah, tetapi mempunyai konsep yang sama. Konsep yang dikemukakan mencakup cara penggunaan bahasa berdasarkan konteks. Dengan kata lain, pragmatik berhubungan dengan makna ujaran yang dihasilkan oleh para partisipan, penutur dan mitra tutur dalam suatu representasi kontekstual tertentu berkaitan dengan prinsip umum penggunaan bahasa.

Investigasi pada penelitian ini berfokus pada aplikasi prinsip kerja sama. Menurut Grice (dalam Brown dan Yule, 1986:31) prinsip kerja sama mempunyai empat maksim, yaitu: kuantitas (quantity), kualitas (quality), hubungan (relation), dan cara (manner). Alasan menginvestigasi prinsip 
kerja sama adalah kenyataan bahwa pemahaman terhadap suatu percakapan tidak cukup hanya melalui analisis linguistik secara murni. Ujaran tidak sekadar mengandung frasa, klausa, dan kalimat. Maksud yang terkandung di balik hadirnya sebuah tuturan dan bagaimana para partsipan bekerja sama dalam sebuah percakapan sehingga percakapan tersebut berlangsung dengan baik merupakan hal yang lebih penting, lebih menarik, dan lebih menantang untuk diteliti.

Penelitian ini bermaksud menjawab pertanyaan secara umum: bagaimana prinsip kerja sama diterapkan di dalam percakapan berbahasa Inggris di radio? Secara khusus, rumusan masalah penelitian adalah: (1) bagaimana rentangan penggunaan prinsip kerja sama dalam percakapan berbahasa Inggris di radio Mas $F M$ ? dan (2)apa tujuan si penutur mengaplikasikan prinsip kerja sama dalam ranah tindak ilokusi?

Tujuan penelitian ini adalah mendeskripsikan penggunaan prinsip kerja sama dalam percakapan berbahasa Inggris di radio. Secara spesifik, penelitian ini mendeskripsikan: (1) rentangan penggunaan prinsip kerja sama dalam percakapan berbahasa Inggris di radio Mas $F M$, dan (2) tujuan si penutur mengaplikasikan prinsip kerja sama dalam ranah tindak ilokusi.

\section{Metode Penelitian}

Rancangan Penelitian. Penelitian ini menggunakan rancangan kualitatif. Studi ini berhubungan dengan rancangan deskriptif kualitatif dan studi kasus berdasarkan pada tiga alasan. Pertama, karakteristik rancangan penelitian deskriptif kualitatif ditunjukkan oleh tujuan penelitian dalam mendeskripsikan pemenuhan dan pelanggaran prinsip kerjasana dan alasanalasan penerapannya. Kedua, karakteristik studi kualitatif diindikasikan oleh prinsip- prinsip metode dan hasil kajian yang lebih berfokus pada proses daripada produk. Ketiga, studi ini berfokus pada interpretasi data berdasarkan rumusan masalah dan berkonsentrasi pada wacana lisan yang direkam dalam bentuk dialog yang dilakukan oleh para partisipan tutur.

Data dan Sumber Data. Data dalam penelitian ini adalah ujaran yang diproduksi oleh para partisipan tutur dalam program percakapan berbahasa Inggris di radio Mas $F M$. Sumber data adalah para presenter atau pembawa acara/penyiar radio, para tamu yang diundang untuk mengisi acara tersebut, dan para pendengar yang berpartisipasi pada acara tersebut melalui telepon ketika mereka mendiskusikan sebuah topik tertentu secara langsung atau on air. Para partisipan tutur sebagai sumber data pada studi ini, terutama pendengar yang berpartisipasi bervariasi, misalnya mahasiswa program studi Bahasa Inggris yang berada di beberapa perguruan tinggi di Malang, guru Bahasa Inggris, siswa sekolah menengah atas, para pegawai atau karyawan, ibu rumah tangga, dan lain-lain yang nota bene mereka bukan penutur asli bahasa Inggris.

Instrumen. Instrumen kunci di dalam penelitian ini adalah peneliti sendiri karena dialah orang yang melakukan observasi hubungan antarsubjek, melakukan studi awal, mengumpulkan data dan menganalisis data. Selanjutnya, peneliti melakukan interpretasi terhadap pemenuhan dan pelanggaran prinsip kerja sama, dan tujuan menerapkan prinsip kerja sama tersebut berdasarkan pengalaman dan latar belakang pengetahuannya. Dalam melakukan tugasnya, peneliti dibantu oleh sejumlah instrumen pendukung, yaitu, pesawat radio, tape recorder dan cassete recorder untuk menjaring data, serta seperangkat tabel untuk menganalisis data.

Pengumpulan Data. Data diperoleh dengan cara merekam percakapan melalui telepon pada sebuah acara berbahasa 
Inggris di stasiun radio Mas FM. Data dikumpulkan ketika acara tersebut berlangsung, yaitu hari Senin hingga hari Jumat pada pukul 19.00 BBWI hingga pukul 20.00 BBWI. Sebelum perekaman dilakukan, ditentukan terlebih dulu jadwal perekamannya. Dalam memperoleh ketercukupan data untuk keperluan analisis, perekaman dilakukan empat kali dalam empat hari, yang terdiri atas empat topik pembahasan. Durasi pembahasan topik diskusi dalam acara tersebut berlangsung sekitar satu jam, termasuk jeda iklan. Untuk mengumpulkan data, peneliti melakukan dua langkah: (1) merekam percakapan yang terjadi di stasiun radio Mas FM, dan (2) mentranskripsikan ujaran-ujaran yang dihasilkan oleh semua partisipan tutur, yaitu para presenter, para tamu, dan para pendengar radio melalui percakapan telepon di radio Mas FM. Transkripsi data dibagi atas empat bagian berdasarkan jadwal pengumpulan data dan topik diskusi.

Analiis Data. Proses analisis data mencakup kegiatan: transkripsi data, reduksi data, displai data, dan penyimpulan. Sepanjang proses pengumpulan data, peneliti mentranskripsikan semua tuturan yang diproduksi oleh para presenter, para tamu, dan para pendengar radio sebagai subjek dalam penelitian ini. Reduksi data bertujuan untuk memroses data mentah sehingga data siap dianalisis. Kegiatan tersebut, sebagaimana dianjurkan oleh Miles dan Huberman (1994) meliputi: menyeleksi, menyederhanakan, memfokuskan, menyarikan, mengkodekan, menyortir dan mengelompokkan tema. Pada penelitian ini, reduksi data merujuk pada proses pengkodean nama-nama subjek, mentranskripsikan percakapan yang terekam, mengelompokkan ujaran-ujaran untuk menentukan eksistensi topik terpilih, dan menyortir data yang tidak relevan. Dalam hal aplikasi prinsip kerja sama diperlukan penetapan indikator pemenuhan dan pelanggaran terhadap prinsip tersebut. Hal tersebut ditunjukkan pada tabel 1 berikut ini.

Tabel 1: Indikator Pemenuhan dan Pelanggaran Prinsip Kerja Sama

\begin{tabular}{|l|l|l|}
\hline \multirow{2}{*}{ Maksim } & \multicolumn{2}{|c|}{ Indikator } \\
\cline { 2 - 3 } & \multicolumn{1}{|c|}{ Pemenuhan } & \multicolumn{1}{c|}{ Pelanggaran } \\
\hline \hline Kuantitas (Quantity) & \multicolumn{1}{|c|}{$\begin{array}{c}\text { Tidak berlebihan } \\
\text { 2. Tidak diulang } \\
\text { 3. Informatif }\end{array}$} & $\begin{array}{l}\text { 1. Berlebihan } \\
\text { 2. Diulang } \\
\text { 3. Kurang informatif }\end{array}$ \\
\hline Kualitas (Quality) & $\begin{array}{l}\text { Terpercaya (didukung oleh bukti } \\
\text { yang adekuat) }\end{array}$ & $\begin{array}{l}\text { Tidak terpercaya (tidak } \\
\text { didukung oleh bukti adekuat) }\end{array}$ \\
\hline Hubungan (Relation) & Rkan topik & Keluar dari topik \\
\hline Cara (Manner) & $\begin{array}{l}\text { 1. Jelas } \\
\text { 2. Singkat } \\
\text { 3. Berurutan }\end{array}$ & $\begin{array}{l}\text { 1. Ambigu } \\
\text { 2. Bertele-tele } \\
\text { Tidak berurutan }\end{array}$ \\
\hline \hline
\end{tabular}

Displai data, sebagaimana dikemukakan oleh Miles dan Huberman (1994) adalah proses pendemonstrasian data baik dalam bentuk teks naratif lisan, matriks, grafik, jaringan, maupun chart. Data yang ditampilkan diharapkan dapat dipahami secara lengkap di dalam bidangnya. Pada penelitian ini data 
ditampilkan dalam bentuk transkripsi percakapan. Triangulasi.

Penelitian ini menerapkan triangulasi untuk mengecek keterpercayaan hasil analisis data. Hal ini bertujuan untuk menghindari kesubjektivitasan opini peneliti dan bias. Tiga macam triangulasi yang diterapkan pada penelitian ini meliputi: triangulasi data, triangulasi metodologi, dan triangulasi teori. Triangulasi data merupakan suatu proses pengumpulan data dari berbagai sumber. Keberagaman sumber data merujuk pada waktu, ruang, dan orang (Denzin, 1978). Validitas data dikonsultasikan dengan para ahli pragmatik, yang dalam ini adalah para pembimbing tesis. Triangulasi metodologi adalah proses penggunaan berbagai metode penelitian untuk mengukur hal yang sama (Denzin, 1978). Jenis triangulasi ini menggunakan metode yang sama pada kesempatan yang berbeda atau metode yang berbeda pada objek penelitian yang sama. Triangulasi dilakukan dengan memberdayakan beberapa metode yang berbeda dalam pengumpulan data. Metode yang digunakan pada penelitian ini adalah melakukan perekaman dengan menggunakan tape recorder.

\section{Hasil Penelitian dan Pembahasan 1. Temuan Penelitian}

Temuan penelitian menjawab dua masalah yang telah dirumuskan. Pertama, klasifikasi data, termasuk implikatur, maksim dan tujuan meliputi: (1) implikatur setiap ujaran, (2) empat maksim dalam prinsip kerja sama sebagaimana dikemukakan oleh Grice dan Leech yang meliputi: kuantitas, kualitas, hubungan, dan cara, dan (3) tujuan si penutur dalam hal ini adalah tindak ilokusi yang mencakup: bersaing (competitive), beramah tamah (convivial), berkolaborasi (collaborative), dan bertentangan (conflictive). Kedua, frekuensi data berhubungan dengan (1) jumlah ujaran pada setiap maksim dalam ranah pemenuhan atau pelanggaannya, (2) kebertumpangtindihan ujaran dalam rentangan penggunaan maksim-maksim dalam prinsip kerja sama, dan (3) tujuan si penutur dalam ranah tindak ilokusi.

\section{a. Klasifikasi Data Berdasarkan Implikatur, Maksim dan Tujuan Penutur (Tindak Ilokusi) \\ Klasifiasi data berdasarkan} implikatur, maksim dan tjuan penutur (tindak ilokusi) merupakan jenis analisis data berdasarkan ujaran-ujaran dalam percakapan berbahasa Inggris di radio Mas $F M$. Ujaran-ujaran tersebut direkam, ditranskrpsikan, direduksi, dikodekan, diinterpretasikan, dan dianalisis berdasarkan maksim-maksim dalam prinsip kerja sama dan tujuan si penutur dalam ranah tindak ilokusi.

\section{b. Keberadaan Frekuensi Data}

Bagian ini mendeskripsikan tiga hal sehubungan dengan keberadaan frekuensi data penelitian, yaitu: (1) rentangan penerapan maksim-maksim dalam prinsip kerja sama, (2) ujaran yang mengandung kebertumpangtindihan maksim, dan (3) tujuan si penutur dalam ranah tindak ilokusi.

\section{c. Rentangan Penerapan Maksim dalam Prinsip Kerja Sama}

Temuan penelitian menunjukkan bahwa keempat maksim dalam prinsip kerja sama diaplikasikan oleh para partisispan tutur, baik pemenuhan maupun pelanggaran maksim-maksim tersebut.

Dari 598 data yang dianalisis, urutan frekuensi pemenuhan maksim pada prinsip kerja sama adalah kuantitas (466 atau 77,93\%), hubungan (449 atau $75,08 \%$ ), cara (325 atau $54,35 \%)$, dan terakhir kualitas (182 atau 30,43\%). 
Pemenuhan dan pelanggaran terhadap dapat diperiksa pada tabel $2 \mathrm{a}$ dan tabel $2 \mathrm{~b}$. maksim-maksim dalam prinsip kerja sama

Table 2a:Rentangan Penerapan Maksim dalam Prinsip Kerja Sama

\begin{tabular}{|c|c|c|c|}
\hline $\mathrm{NO}$ & MAKSIM & JUMLAH & PROSENTASE \\
\hline 1 & 2 & 3 & 4 \\
\hline \multirow[t]{3}{*}{1} & \multirow[t]{3}{*}{ KUANTITAS } & $\sqrt{ }=342$ & \\
\hline & & $X=124$ & \\
\hline & & $\Sigma=466$ & $77,93 \%$ \\
\hline \multirow[t]{3}{*}{2} & \multirow[t]{3}{*}{ HUBUNGAN } & $\sqrt{ }=292$ & \\
\hline & & $X=157$ & \\
\hline & & $\Sigma=449$ & $75,08 \%$ \\
\hline \multirow[t]{3}{*}{3} & \multirow[t]{3}{*}{ CARA } & $\sqrt{ }=233$ & \\
\hline & & $X=92$ & $54,35 \%$ \\
\hline & & $\Sigma=325$ & \\
\hline \multirow[t]{3}{*}{4} & \multirow[t]{3}{*}{ KUALITAS } & $\sqrt{ }=106$ & \\
\hline & & $X=76$ & \\
\hline & & $\Sigma=182$ & $30,43 \%$ \\
\hline
\end{tabular}

Tabel 2b: Contoh Penerapan Maksim dalam Prinsip Kerja Sama

\begin{tabular}{|c|c|l|l|}
\hline NO & MAKSIM & \multicolumn{1}{|c|}{ PEMENUHAN } & \multicolumn{1}{c|}{ PELANGGARAN } \\
\hline 1 & $\mathbf{2}$ & \multicolumn{1}{|c|}{$\mathbf{3}$} \\
\hline \hline 1 & KUANTITAS & $\begin{array}{l}\text { Bless The Lord. It's a good } \\
\text { weather today. I have no rain. } \\
\text { This is kind to me. (VC34) }\end{array}$ & $\begin{array}{l}\text { Betrayal? Oh, what's that? } \\
\text { (ER3) }\end{array}$ \\
\hline 2 & HUNUNGAN & $\begin{array}{l}\text { I think, I have a phobia kind } \\
\text { of cockroach. (RD9) }\end{array}$ & $\begin{array}{l}\text { And, have you got a dinner? } \\
\text { (VC21) }\end{array}$ \\
\hline 3 & CARA & $\begin{array}{l}\text { Yes, this is on air. So, we are } \\
\text { talking about love betrayal, } \\
\text { actually. } \\
\text { (VC2) }\end{array}$ & $\begin{array}{l}\text { I hope you are not to be angry } \\
\text { to mecause I have some } \\
\text { fried bugs and fried flies. } \\
\text { (VC24) }\end{array}$ \\
\hline 4 & KUALITAS & $\begin{array}{l}\text { Well, I feel exhausted actually } \\
\text { today for many activities } \\
\text { because my friends and me } \\
\text { get any kind of information of } \\
\text { flying ticket to every airlines. } \\
\text { (SR15) }\end{array}$ & I'll try to kill her. (ER5) \\
\hline
\end{tabular}

$\begin{array}{ll}\text { VC: Vincent } & \text { RD: Rudi } \\ \text { ER: Erik } & \text { AD: Andi } \\ \text { SR: Sri } & \text { TN: Trisna } \\ \text { ID: IndraDewi } & \end{array}$




\section{d. Ujaran dengan Kebertumpang- tindihan Maksim}

Temuan penelitian menunjukkan bahwa terdapat 525 ujaran yang bertumpang tindih antara aspek pemenuhan dan pelanggaran terhadap maksim-maksim dalam prinsip kerja sama. Contohnya dapat diperiksa pada tabel 4 .

Tabel 4:Ujaran dengan Kebertumpangtindihan Maksim dalam Prinsip Kerja Sama

\begin{tabular}{|c|c|c|c|c|c|c|c|}
\hline \multirow[t]{2}{*}{ NO } & \multirow{2}{*}{\multicolumn{2}{|c|}{ DATA }} & \multirow[t]{2}{*}{ Kode } & \multicolumn{4}{|c|}{ MAKSIM } \\
\hline & & & & KN & KL & HB & CR \\
\hline 1 & 2 & & 3 & 4 & 5 & 6 & 7 \\
\hline 1 & $\begin{array}{l}\text { Because you are the exp } \\
\text { many girls }\end{array}$ & You have so many & $\overline{\mathrm{AD} 12}$ & $\bar{X}$ & $\bar{X}$ & $\sqrt{1}$ & \\
\hline 2 & $\begin{array}{l}\text { Okay, Aji thank you very } \\
\text { experience, which is real }\end{array}$ & $\begin{array}{l}\text { uch for sharing your } \\
\text { nice to know. }\end{array}$ & $\begin{array}{l}\text { ID } \\
147\end{array}$ & $\sqrt{ }$ & & $\sqrt{ }$ & \\
\hline 3 & $\begin{array}{l}\text { I just wanna to kill the ti } \\
\text { happy with this crazy. } B \mathrm{~b} \\
\text { you have to giveeen me } \\
\text { have to think first ... thin }\end{array}$ & $\begin{array}{l}\text { Sometimes it's } \\
\text { it's okay, so anyway } \\
\text { inion about that we } \\
\text { irst. }\end{array}$ & VC79 & $\mathrm{X}$ & & $X$ & \\
\hline
\end{tabular}

Contoh no. 1 (AD12) menunjukkan kebertumpangtindihan dari tiga maksim, yaitu dua pelanggaran maksim (kuantitas dan kualitas) dan satu pemenuhan maksim hubungan. Ujaran no. 2 (ID147) menunjukkan kebertumpangtindihan pemenuhan dua maksim, yaitu maksim kuantitas dan maksim hubungan. Dan contoh ujaran no. 3 (VC79) menunjukkan kebertumpangtindihan atas pelanggaran maksim kuantitas dan hubungan.

\section{e. Tujuan Penutur dalam Ranah Tindak Ilokusi}

Setiap ujaran yang dihasilkan oleh partisipan tutur dalam percakapan mempunyai tujuan tertentu. Secara pragmatis, tujuan ini berkaitan dengan tindak ilokusi. Leech (1983:162) mengkategorikan empat tipe tindak ilokusi berdasarkan fungsinya: kompetitif (competitive), beramah tamah (convivial), berkolaborasi (collaborative), dan bertentangan (conflictive). Kompetitif adalah tujuan ilokusi bersaing dengan tujuan sosial, misalnya: memerintah, meminta, menuntut, mengemis. Fungsi tindak ilokusi beramah tamah (convivial) adalah tujuan ilokusi yang sejalan dengan tujuan sosial, misalnya: menawarkan, mengajak, mengundang, menyapa, mengucapkan terima kasih, membuat lelucon, berkomentar, dan mengucapkan selamat. Fungsi berkolaborasi (collaborative) adalah tujuan ilokusi yang tidak menghiraukan tujuan sosial, misalnya: menyatakan, malapor, bertukar pendapat, mengumumkan, dan menginstruksikan. Fungsi berkonflik (conflictive) adalah tujuan ilokusi yang bertentangan dengan tujuan sosial, misalnya: mengancam, menyalahkan, menyumpahi, dan memarahi.

Temuan penelitian menunjukkan bahwa tiga fungsi tindak ilokusi, yaitu kompetitif, beramah tamah dan berkolaborasi diterapkan oleh para partisipan tutur. Fungsi ilokusi yang tidak digunakan adalah fungsi berkonflik. 
Perinciannya dapat diperiksa pada tabel $4 a$ dan $4 b$ berikut.

Tabel 4a:Tujuan Penutur dalam Ranah Tindak Ilokusi

\begin{tabular}{|c|c|c|c|}
\hline Tindak Ilokusi & Subfungsi TI & Jumlah & Prosentase \\
\hline 1 & 2 & 3 & 4 \\
\hline \multirow{5}{*}{$\begin{array}{l}\text { Kompetitif } \\
\text { (Competitive) }\end{array}$} & Memerintah & 9 & $1.50 \%$ \\
\hline & Meminta & 0 & \\
\hline & Menuntut & 9 & $1.50 \%$ \\
\hline & Mengemis & 0 & \\
\hline & $\Sigma$ & 18 & $3.00 \%$ \\
\hline \multirow{7}{*}{$\begin{array}{l}\text { Beramah tamah } \\
\text { (Convivial) }\end{array}$} & Mengundang & 2 & $0.33 \%$ \\
\hline & Menyapa & 61 & $1.02 \%$ \\
\hline & $\begin{array}{l}\text { Mengucapkan terima } \\
\text { kasih }\end{array}$ & 13 & $2.17 \%$ \\
\hline & Membuat lelucon & 40 & $6.69 \%$ \\
\hline & Berkomentar & 43 & $7.19 \%$ \\
\hline & $\begin{array}{l}\text { Mengucapkan } \\
\text { selamat }\end{array}$ & 0 & $0 \%$ \\
\hline & $\Sigma$ & 172 & $28.76 \%$ \\
\hline \multirow{7}{*}{$\begin{array}{l}\text { Berkolaborasi } \\
\text { (Collaborative) }\end{array}$} & Menyatakan & 134 & $22.41 \%$ \\
\hline & Melapor & 87 & $14.55 \%$ \\
\hline & Berpendapat & 77 & $12.89 \%$ \\
\hline & Bertanya & 107 & $17.89 \%$ \\
\hline & Mengumumkan & 0 & $0 \%$ \\
\hline & Menginstruksikan & 3 & $0.50 \%$ \\
\hline & $\Sigma$ & 408 & $68.24 \%$ \\
\hline \multirow[t]{2}{*}{$\begin{array}{l}\text { Berkonflik } \\
\text { (Conflictive) }\end{array}$} & & $\mathbf{0}$ & $\mathbf{0 \%}$ \\
\hline & $\Sigma$ & 598 & $100 \%$ \\
\hline
\end{tabular}

Tabel 4b:ContohTujuan Penutur dalam Ranah Tindak Ilokusi

\begin{tabular}{|c|c|c|}
\hline Tindak Ilokusi & Subfungsi TI & Contoh ujaran \\
\hline 1 & 2 & 3 \\
\hline \multirow[t]{4}{*}{$\begin{array}{l}\text { Kompetitif } \\
\text { (Competitive) }\end{array}$} & Memerintah & $\begin{array}{l}\text { By the way, can you help me to correct my } \\
\text { English. (ST3) }\end{array}$ \\
\hline & Meminta & - \\
\hline & Menuntut & $\begin{array}{l}\text { Aha, actually you should not bring that on air. } \\
\text { (AD11) }\end{array}$ \\
\hline & Mengemis & - \\
\hline \multirow[t]{3}{*}{$\begin{array}{l}\text { Beramah tamah } \\
\text { (Convivial) }\end{array}$} & Mengundang & $\begin{array}{l}\text { One thing that maybe I can help you Dewa } \\
\text { because Mas FM also has a community and next } \\
\text { Sunday there will be a meeting. So, I invite } \\
\text { you.... join us. (ID101) }\end{array}$ \\
\hline & Menyapa & $H i$, Erik! (TN4) \\
\hline & $\begin{array}{l}\text { Mengucapkan terima } \\
\text { kasih }\end{array}$ & $\begin{array}{l}\text { Okay, Aji thank you very much for sharing your } \\
\text { experience, which is really nice to know. } \\
\text { (ID147) }\end{array}$ \\
\hline
\end{tabular}




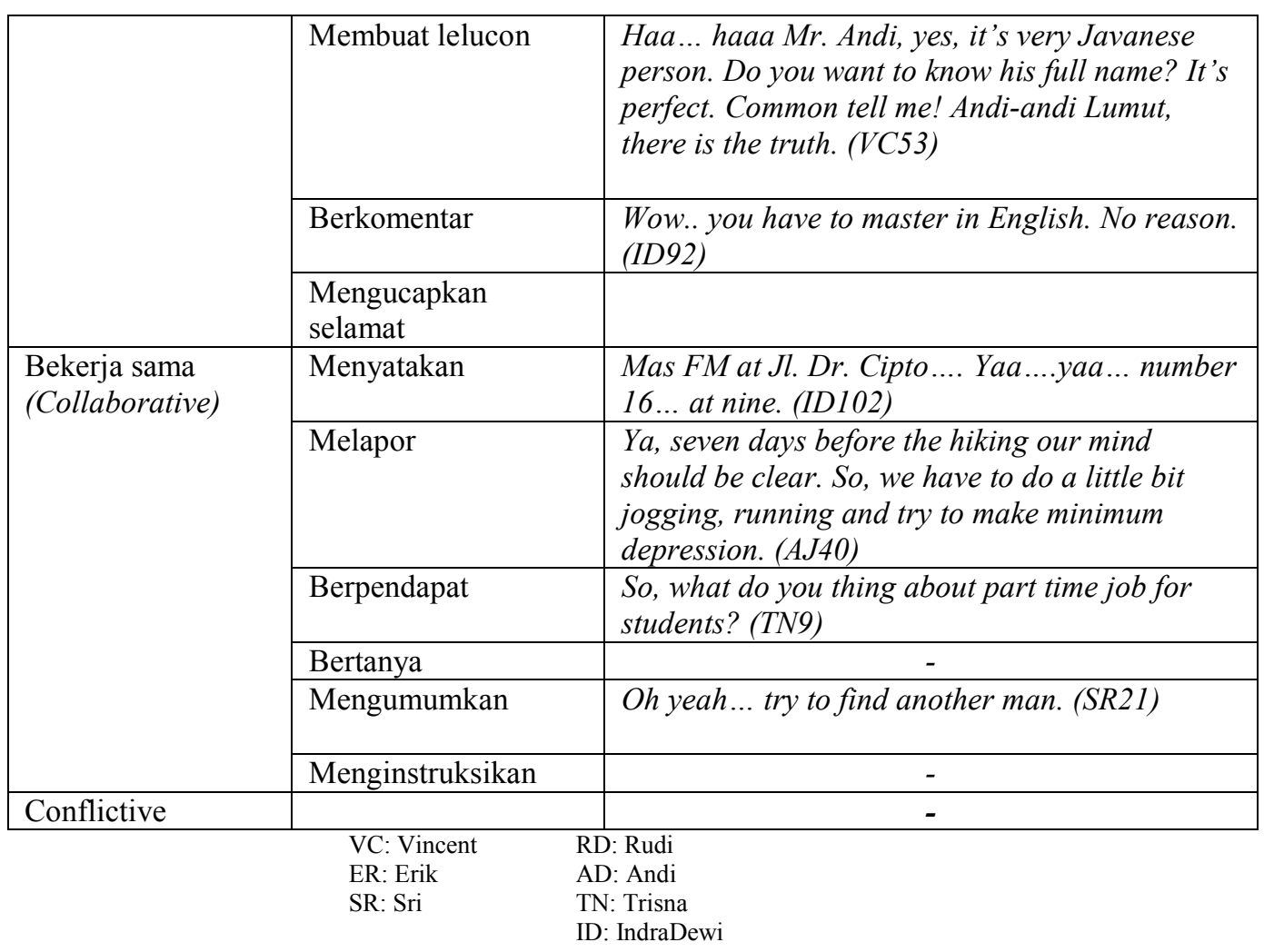

\section{Pembahasan}

Pembahasan merujuk pada hasil temuan penelitian berdasarkan kedua rumusan masalah penelitian. Pertama adalah rentangan penerapan prinsip kerja sama dalam percakapan berbahasa Inggris di radio Mas FM. Kedua adalah tujuan si penutur menerapkan prinsip kerja sama tersebut dalam ranah tindak ilokusi.

\section{Rentangan Penerapan Prinsip Kerja Sama dalam Percakapan Berbahasa Inggris di Radio Mas FM}

Pertama, rentangan penerapan maksim-maksim dalam prinsip kerja sama oleh para partisipan tutur dalam percakapan berbahasa Inggris di radio Mas FM secara frekuentatif adalah kuantitas, hubungan, cara, dan kualitas.

Leech (1983: 84) mengatakan bahwa maksim kuantitas dan kualitas biasanya hadir bersamaan, karena keduanya secara frekuentatif saling melengkapi. Sejumlah informasi yang dikemukakan oleh si penutur dibatasi oleh harapan si penutur untuk menghindari mengatakan hal yang tidak benar. Untuk alasan ini, Harnish (1976 dalam Leech, 1983:85) mengajukan kombinasi maksim-maksim sebagai "Make the strongest relevant claim justifiable by your evidence" (buatlah klaim hubungan yang terkuat dengan bukti.). Lebih lanjut, Leech (1983:85) menjelaskan bahwa 'kekuatan' merujuk pada sejumlah informasi yang dikomunikasikan. Ia menambahkan, inferensi informal pada kombinasi maksim kuantitas - kualitas dapat diperhitungkan.

Temuan penelitian bahwa para partisipan tutur memenuhi atau menaati maksim kuantitas terbanyak secara frekuentatif dapat diterima karena media yang digunakan dalam melakukan percakapan tersebut adalah radio. Dalam kondisi percakapan semacam ini para partisipan tutur harus dapat mengatur waktu sebijaksana mungkin. Oleh karena itu, si penutur berbicara seperlunya dan 
seinformatif mungkin berdasarkan topik yang dibahas. Hal ini sesuai dengan maksim kuantitas yaitu bahwa ujaran si penutur harus disampaikan tidak lebih dari yang diperlukan kepada mitra tutur. Hal ini sesuai dengan indikator pemenuhan maksim kuantitas, yaitu (1) tidak berlebihan, (2) tidak mengulang, dan (3) informatif (informasi yang adekuat). Di sisi lain, pelanggaran maksim kuantitas mengindikasikan bahwa ujaran yang diproduksi oleh si penutur: (1) berlebihan, (2) diulang, dan (3) kurang informatif (informasi yang tidak adekuat).

Ujaran Vincent pada pembahasan topik pertama 'Love Betrayal' (Pengkhianatan Cinta), "Bless the Lord. It's good weather today. I have no rain. This is kind to me (VC34)" (Puji Tuhan hari ini cuaca bagus) menerapkan maksim kuantitas. Ujaran ini memenuhi indikator maksim kuantitas. Ujaran tersebut tidak berlebihan dan informatif. Terutam informasi mengenai cuaca. Di sisi lain, ujaran salah seorang pendengar radio, Erik, "Betrayal? Oh. What's that? (ER3)" melanggar maksim kuantitas. Erik mengulang hal yang sudah disampaikan oleh presenter. Selain itu, ujaran ini berlebihan karena hal yang disampaikan oleh Vincent, presenter,sebenarnya sudah cukup jelas. Akan tetapi, pengulangan kata 'betrayal' (pengkhianatan) oleh Erik sebenarnya dapat diterima karena dua alasan. Pertama, Erik tidak begitu mengenal istilah itu, sehingga ia ingin memastikan kata yang diucapkan oleh presenter. Kedua, Erik terkejut atau tidak yakin dengan topik yang sedang didiskusikan karena ia tidak mengikuti program tersebut dari awal. Ketika ia ingin mengemukakan pendapat, ia tidak tahu dengan jelas topik yang sedang didiskusikan.

Selanjutnya, maksim kualitas adalah bahwa ujaran yang dihasilkan oleh penutur mengandung unsur kebenaran. Indikator pemenuhan maksim ini adalah kebenaran ujaran yang didukung oleh bukti adekuat. Di pihak lain, indikator pelanggaran maksim ini adalah ketidakbenaran yang disertai dengan bukti yang tidak adekuat.

Ujaran Sri, "Well, I feel exhausted actually today for many active-ties because my friends and I get any kind of information of flying ticket to every airline (SR15," memenuhi unsur kebenaran. Sri mengutarakan kondisi kesehatannya bahwa ia sangat lelah. Sri menjelaskan alasan ia lelah. Berdasarkan indikator maksim kualitas ujaran Sri tersebut mengandung unsur kebenaran dengan informasi yang adekuat. Contoh kedua adalah pelanggaran maksim kualitas, misalnya ujaran Erik, "I'll to' kill her (ER5)." Ujaran ini tidak mengandung unsur kebenaran. Sebenarnya, Erik ingin membuat lelucon melalui ujarannya itu karena dia tidak setuju dengan gadis yang mengkhianati cinta pasangannya.

Maksim huungan juga banyak digunakan oleh para partisipan tutur dalam percakapan di radio MasFM. Hal yang didiskusikan relevan dengan topik yang sedanag dibahas. Sebagian besar partisipan mengutarakan gagasan dan pendapatnya mengenai topik yang dibahas. Ujaranujaran tersebut termasuk penggunaan maksim hubungan. Indikatornya adalah bahwa ujaran mereka berdasarkan topik.

Leech (1983:93) menyatakan maksim hubungan sebagai "suatu jenis informasi khusus". Informasi tersebut merujuk pada sebuah topik tertentu yang didiskusikan. Ujaran Rudi, "I think, I have a phobia kind of cockroach (RD9)" relevan dengan topik yang sedang dibahas, yaitu ketakutan terhadap sesuatu (Fear of Something). Rudi, seorang audience, mempunyai rasa ketakutan terhadap kecoa. Pada percakapan berikutnya, Rudi menceritakan lebih jauh dan berbagi pengalaman mengenai kenapa dan bagaimana ia takut pada serangga itu. Oleh karena itu, ujaran Rudi tersebut benar-benar 
mengindikasikan pemenuhan maksim hubungan. Ia mencoba memberikan suatu infomasi khusus - ketakutan terhadap sesuatu. Di sisi lain, pelanggaran maksim ini ditunjukkan oleh ujaran Vincent, "And, have you got a dinner? (VC21)". Sebagai seorang presenter seharusnya Vincent menyarankan kepada pendengar radio untuk mendiskusikan topik "Love Betrayal" (Pengkhianatan Cinta). Sebenarnya ujaran Vincent tersebut dapat dimaklumi dalam konteks bahwa cara Vincent melakukan percakapan dengan salah seorang pendengar mengisyaratkan bahwa mereka sudah saling mengenal. Tampaknya si pendengar ini sudah sering berpartisipasi dalam acara percakapan berbahasa Inggris di radio MasFM. Ia bukanlah pendatang baru. Tampaknya ia telah mengenal Vincent, presenter, sehingga percakapan tersebut belangsung sangat akrab, bebas, penuh dengan lelucon, dan bahkan keluar dari topi, walaupun akhirnya mereka kembali kepada topik.

Lebih jauh, Leech (1983; 94) menyatakan bahwa relevansi sebuah ujaran dengan ujaran yang lain merupakan bagian dari konsep relevansi yang lebih luas, hubungan sebuah tuturan terhadap situasi tuturnya. Dalam pandangan yang lebih luas, Leech (1983: 99) mendefinisikan relevansi sebagai "An utterance $U$ is relevant to speech situation to the extent that $U$ can be interpreted as contributing goal(s) of $s$ and $h$ " (Sebuah ujaran berhubungan dengan situasi tutur dalam rentang bahwa ujaran tersebut dapat diinterpretasikan sebagai pengkontribusian tujuan si penutur dan mitra tutur).

$$
\text { Leech (1983:100) mengatakan }
$$

bahwa maksim cara jarang terdapat pada penjelasan implikatur percakapan. Lebih jauh, Grice ( dalam Leech, 1983: 100) melihat bahwa maksim ini tidak lebih penting daripada maksim kualitas dan berbeda dari yang lain dalam "tidak menghubungkan sesuatu dengan hal yang diutarakan, tetapi lebih kepada bagaimana cara mengatakan sesuatu". Dalam hal ini jelas bahwa baik maksim cara maupun maksim hubungan merupakan hal penting dalam komunikasi verbal pada sudut pandang tindak ilokusi. Dalam hal ini, fungsi maksim cara melengakapi dan mendukung maksim hubungan.

Pada maksim cara, hasil penelitian menunjukkan bahwa beberapa ujaran cukup jelas dan mudah dimengerti oleh mitra tutur. Hal ini sesuai dengan prinsip bahwa sebuah ujaran memenuhi maksim cara apabila ujaran tersebut jelas atau tidak ambigu. Pemenuhan maksim cara mengindikasikan bahwa ujaran: (1) jelas, (2) tidak amabigu, (3) singkat, dan (4) berurutan. Sebaliknya, pelanggaran terhadap maksim cara mengindikasikan bahwa ujaran: (1) tidak jelas, (2) bersifat ambigu, (3) bertele-tele, dan(4) tidak berurutan.

Tuturan Vincent, "Yes, this is on air. Therefore, we are talking about love betrayal; actually, (VC2)" memenuhi indikator maksim cara. Tuturan itu jelas dan mudah dimengerti. Vincent mengatakan bahwa progam ini bersifat langsung (on air) dan topik yang didiskusikan adalah pengkhianatan cinta. Ujaran tersebut jelas dan singkat. Sementara, ujaran Vincent yang lain, "I hope you are not to be angry to me because I have some fried bugs and fried flies (VC24)" mengindikasikan pelanggaran maksim cara. Ujaran tersebut tidak jelas dan bertele-tele. Namun dari sudut pandang pragmatik ujaran tersebut dapat diterima karena sebagai seorang presenter, Vincent harus bersikap ramah kepada para pendengar. Untuk itu, ia banyak membuat lelucon dengan mengatakan sesuatu yang mungkin sedikit kasar dan terkesan mengejek kaena ia sudah kenal akrab dengan si pendengar tersebut.

Kesimpulannya, pemenuhana keempat maksin, kuantitas, hubungan, cara, dan kualitas memungkinkan seorang 
partisipan tutur mengkomunikasikan sebuah asumsi bahwa ia dapat bekerja sama dengan partisipan lain dalam konteks percakapan. Hal ini sesuai dengan hal yang diutarakan oleh Leech (1983:82) bahwa keempat maksim dalam prinsip kerja sama tersebut mempunyai fungsi regulasi tentang hal yang dikatakan yang mempunyai kontribusi terhadap tindak ilokusi aau tujuan percakapan.

\section{Tujuan si Penutur dalam Ranah Tindak Ilokusi (TI)}

Leech (1983:104) menjelaskan bahwa tindak ilokusi adalah tindak berbahasa atau performasi tuturan yang mengkomunikasikan sesuatu, yang berdampak terrtentu pada diri si pendengar atau mitra tutur. Kategori tindak ilokusi menurut Leech mempunyai fungsi tertentu untuk menentukan tujuan atau maksud si penutur. Penelitian ini menggunakan pengkategorian tindak ilokusi yang dikemukakan oleh Leech dalam menganalisis data. Kategori tindak ilokusi tersebut adalah (1) kompetitif (competitive),

(2) beramah tamah (convivial), berkolaborasi (collaborative), dan bertentangan (conflictive).

Temuan penelitian menunjukkan fungsi berkolaborasi mendominasi tujuan percakapan (408 data atau 68,24\%). Hal ini dapat dierima karena secara umum sebuah percakapan memerlukan kolaborasi yang baik di antara para partisipan tuturnya, sehingga percakapan tersebut dapat berjalan dengan lancar dan indah. Hampir semua subfungsi berkolaborasi: menyatakan, malaporkan, berbagi pendapat, bertanya, menginstruksikan diaplikasikan oleh para partisipan, kecuali subfungsi mengumumkan. Subfungsi mengumumkan tidak diaplikasikan pada program acara ini karena program acara ini tidak dirancang untuk hal tersebut. Peringkat kedua diduduki oleh fungsi beramah tamah (172 data atau 28,76\%). Hampir semua subfungsi, yaitu menawarkan, mengundang, menyapa, berterima kasih, membuat lelucon, dan berkomentar diaplikasikan oleh para partisipan tutur, kecuali mengucapkan selamat. Faktanya, tidak ada seorangpun partisipan tutur yang mengucapkan selamaat kepada yang lain, karena program ini didesain untuk bertukar pendapat mengenai topik yang dilontarkan oleh presenter. Dengan kata lain, program ini tidak didesain untuk mengirimkan sesuatu atau mengucapkan selamat kepada partisipan lain. Subfungsi mengucapkan selamat mungkin dirancang pada program acara lain, misalnya progam acara ulang tahun. Peringkat ketiga adalah penggunaan fungsi kompetitif (18 data atau 3,00\%). Dalam percakapan ini para partisipan tutur jarang melakukan tindak persaingan untuk tujuan sosial. Dari keempat subfungsi kompetitif, yang diaplikasikan oleh para partisipan tutur adalah memerintah dan menuntut. Seorang presenter memrintah dan menuntut partisipan tutur yang lain untuk memberikan dan menggali atau mengeksplorasi ide, pendapat, opini atau pengalamannya tentang topik. Di sisi lain, subfungsi meminta dan mengemis tidak diaplikasikan karena tidak diperlukan oleh para partisipan tutur dalam konteks percakapan ini. Terakhir, temuan penelitian tidak menunjukkan penggunaan fungsi bertentangan oleh para partisipan tutur. Fungsi bertentangan tidak diaplikasikan karena perckapan pada program acara ini bukanlah merupakan debat. Para partisipan tutur berbicara secara alamiah, santai, nyaman, dan untuk hiburan. Oleh karena itu, mereka menghindari konflik dengan yang lain, meskipun terkadang ujaran mereka bersifat mengejek, tetapi masih berada dalam situasi berkelakar. Contoh masing-masing aplikasi fungsi pada tindak ilokusi dan subfungsinya dipaparkan berikut ini.

Pertama, salah satu subfungssi berkolaborasi adalah menyatakan. Contohnya adalah ujaran Sri, "Of course, it 
is not their mind, you know. They are not normal persons I think. And they should be in the national geographic channel animal. Ya, like the animals. You know that movie, that they are not human beings. Animals like to kill their friends because they want to attract another... another female but likewise another female, so, the national geographic. It's really out of the mind, you know (SR19).” Dalam ujarannya ini Sri menyatakan keyakinannya dengan berbagi pendapat tentang topik yang sedang diperbincangkan, yaitu pengkhianatan cinta(love betrayal).

Kedua, contoh pengaplikasian fungsi beramah tamah adalah ujaran Vincent, "Haa.. haaa... Mr. Andi, yes, it's a very Javanese person Do you want to know his full name? It's perfect. Common tell me! Mr. Andi-Andi Lumut, there is the truth (VC53)." Dalam ujarannya, Vincent beusaha menyelaraskan dengan tujuan sosial dengan cara berkelakar.

Terakhir, sebagaimana dikatakan oleh Leech (1983:104) bahwa kompetitif adalah tindak ilokusi yang bertujuan bersaing dengan tujuan sosial. Temuan penelitian menunjukkan bahwa terdapat beberapa tuturan yang mengandung fungsi kompetitif. Ujaran Sinta, "By the way, can you help me to correct my English (ST3)" mengandung fungsi kompetitif dengan subfungsi memerintah (ordering). Tuturan tersebut menunjukkan bahwa Sinta memerintah Indra Dewi, presenter untuk mengoreksi kesalahannya dalam berbahasa Inggris.

\section{Penutup}

Keempat maksim dalam prinsip kerja sama diterapkan oleh para patisipan tutur. Penggunaan keempat maksim tersebut secara frekuentratif bervariasi dari yang terbanyak hingga paling sedikit. Ditemukan juga banyak terjadi tumpang tindih dan pelanggaran terhadap maksimmaksim tersebut. Pelanggaran maksim terbanyak terjadi pada maksim hubungan. Pelanggaraan terhadap maksim ini cukup beralasan karena beberapa pendengar (audience) mengenal presenter dengan baik. Mereka adalah pendengar setia yang sering berpartisipasi pada acara ini. Mengingat mereka sudah akrab dengan para presenter, dalam bergabung dengan program ini mereka seringkali berkelakar, pembicaraannya keluar dari topik dan cenderung bertele-tele. Dengan demikian, sebuah ujaran dapat dianalisis berdasarkan sudut pandang yang bervariasi karena ujaran tersebut mengandung pemenuhan dan atau pelanggaran terhadap beberapa maksim.

Dari keempat fungsi tindak ilokusi, satu-satunya fungsi yang tidak diterapkan oleh para partisipan tutur di radio Mas FM adalah fungsi bertentangan (conflictive). Hal ini dihindari oleh para partisipan tutur karena percakapan melalui telepon secara langsung siar (on air) adalah jenis percakapan tidak bersemuka yang dilakukan tanpa mengetahui ekspresi mimik dan gestur para patisipan tuturnya.

\section{Daftar Pustaka}

Brown, G. and George Yule. 1983. Discourse Analysis. Cambridge: Cambridge University Press

Brown, Penelope and Levinson, Stephen C. 1987. Politeness. Some Universals in Language Usage. Cambridge: Cambridge University Press

Edmondsond, W.1981. Spoken Discourse: A Model of Analysis. London and New York: Longman

Grice, H.P. 1975. "Logic and Conversation", in Peter Cole and Jerry L., Morgan (eds) Syntax and Semantics 3: Speech Acts. New York: Academic Press, Inc.,pp 4148 
Leech, Geoffrey. 1983. Principles of Pragmatics. London and New York: Longman

Levinson, Stephen C. 1992. Pragmatics. Cambridge: Cambridge University Press

Miles, $\mathrm{M}$ and Huberman, M.1994. Qualitative Data Analysis: An Expanded Sourcebook. Beverly Hills: SAGE Publication Inc
Renkema, Jan. 1993. Discourse Studies. An Introductory Textbook. Amsterdam/ Philadelphia: John Benjamins Publishing Company

Winarsih, Suko. 2007. The Cooperative and Politeness Principlkes in Radio Broadcasting Conversations. Tesis - Universitas Negeri Malang, tidak diterbitkan 